\title{
A kapwa-infused paradigm in teaching Catholic theology/catechesis in a multireligious classroom in the Philippines
}

\section{Willard Enrique R. Macaraan}

\begin{abstract}
The increasing religious diversity in educational space has raised a legitimate question on how Catholic theology/ catechesis must be taught in Philippine Catholic universities given the institutional mandate to educate students "into the faith of the Church through teaching of Christian doctrine in an organic and systematic way" (Wuerl, 2013, 1). On this note, the paper makes reference to "centered pluralism" (CP), a positional posture espoused by Georgetown University in dealing with this predicament. In an attempt to (re) appropriate CP into local context, there is a need to explore the Filipino conception of self/others as enveloped within the indigenous concept of kapwa. Hereon, the paper finds that CP is not just feasibly suitable in local context but with kapwa's more inclusive description of the relationship of self and others, a CP-based teaching paradigm in theology/ catechesis is a promising project in the educational scene of the Philippines.
\end{abstract}

\section{KEYWORDS}

centered pluralism, kapwa, religious education, student mobility, student-centered learning, theological education 


\section{1 | INTRODUCTION}

Just like any socially constructed enterprise, theological education is subject to reconstruction, especially when times and issues change (Aleshire, 2008, 3). ${ }^{1}$ Recent years have seen how theological classrooms in many universities in the Philippines have not only become culturally-diverse (multicultural), they have also become religiously plural (multireligious). This emerging trend has implications for the current state of Philippine Catholic academia that is known to embrace a core curriculum based on Catholic tradition. On top of the government-mandated general education subjects are subjects on Catholic theology/catechesis. With diversity becoming a norm in educational settings, various issues have been raised. From a pedagogical standpoint, can there be a theological pedagogy that remains faithful to Catholic confession while actively engaging non-Catholics? From an institutional viewpoint, must Catholic universities entirely lose their confessional bias in response to the growing multi-religiosity of theology classrooms and adopt a more interfaith/ecumenical approach to teaching religion? Or should they maintain their hold on their religious heritage and demand that non-Catholics adjust, adapt, and comply? Or is it enough to simply embrace an attitude of (passive) mutual respect as John Paul II implies in Ex Corde Ecclesiae, "Non-Catholic members are required to respect the Catholic character of the University, while the University in turn respects their religious liberty" (1990, para. 27)?

Since the dawn of the new millennium, the Philippines has implemented significant initiatives on adopting and integrating student-centered learning (SCL) approaches in its educational system (De Guzman, 2004). This paper argues however that the SCL framework may not be enough to provide the best classroom experience for both teachers and students within a multireligious theology/catechesis classroom. While it may provide the best learning paradigm to benefit students in constructing their own religious meaning, any tendency to overly depend on and overdo it may result in purely subjective theological musings that do not reflect or may be contrary to the content of the Catholic faith. Hence, SCL alone may not be effective and helpful to teachers of theology/catechesis who, in general, are institutionally expected to transfer the content of the Catholic faith into their students. It is within this situation of teaching theology/catechesis (and not much in the situation of learning it), that this paper delves by proposing a complementary (teaching) paradigm to the existing SCL paradigm, particularly for theology/catechesis classes that are expected to promote or at least preserve Catholic teachings despite the increasing diversity of faith and religious affiliations among students.

The SCL framework when implemented in Catholic theology/catechesis class is limited in its ability to address the predicament of professors trying to establish a positional balance between the obligation to teach Catholic theology/catechesis and the obligation to empower students to construct their own learning, which may open up subjective articulations contrary or inimical to Catholic "hard" truths (doctrines and dogmas). Bevans and Shroeder highlight this same predicament in their invitation to rethink pedagogy "without losing its ground on Catholic tradition" $(2004,143)$ particularly in the project of contextualizing Western-articulated Catholic teachings in developing Third World nations.

Aside from the concern over fidelity to (Catholic) content, existing literature on SCL also suggests a confusion as to how much space must be allowed for students to construct their own learning without negatively affecting the expected content coverage of any subject. This has been a legitimate concern of professors adopting an SCL approach (Cooper, MacGregor, Smith, \& Robinson, 2000; Cooper, 1995; Felder \& Brent, 1999; Tien, Roth, \& Kampmeier, 2002) particularly those who are teaching prerequisite courses/subjects (the contents of which are essentially useful to downstream courses/subjects). Their predicament is hinged between the desire to allow students more space for learning and their obligation to cover the mandated content of the syllabus. Most teachers who have failed to cover the required content of their syllabi have also affirmed that their students have shown increased learning (Cooper, MacGregor, Smith, \& Robinson, 2000). Between a desirable improvement in their students' learning and their frustration over not covering enough of the syllabi, teachers' adoption of the SCL framework

*The author wishes to acknowledge the very helpful comments by Thomas Pearson and the two anonymous referees during the review process of this article. 
varies. Felder and Brent, however, believe that the main focus of teaching must be on what students learn and not so much on what teachers present: "the goal should not be to cover the syllabus but to uncover the most important parts of it" (1999, 276). Instead of traditional lecture forms where students merely sit and listen, by engaging them actively in exercises, group work, and so forth, students' learning is increased. As for covering the expected content, Felder and Brent suggest that teachers give their students supplementary handouts and readings with a strong reminder that it may be included in tests and examinations, to reinforce reading. In this way, learning is achieved and the syllabus is substantially covered.

This paper does not challenge or question the effectiveness of the SCL framework insofar as student learning is concerned. The main issue put forward here is the limitation of SCL, at least in confessional theology/catechesis, to provide clarity of position or direction for teachers to embrace since SCL allows a more fluid, flexible, and postmodern learning ambiance. Within the SCL framework learning is improved and students are engaged to actively form their own religious meanings and musings, but that may prove inimical to how most of these theology/catechesis subjects are primordially designed - as core subjects for a faith-based education that must reflect the institutional Catholic identity and heritage. To veer away from that or even to compromise that intention by opening space for possible non-Catholic or anti-Catholic sentiments within an SCL framework may not be acceptable. In the end, there is a significant aspect in any (Catholic) theology/catechesis within a multi-religious classroom that can hardly be accomplished by sole adoption of a SCL approach. Another framework, particularly for the teaching component, may be needed, one that would provide positional direction for teachers in teaching theology/catechesis within a student-centered multi-religious classroom.

In this light, this paper examines what Georgetown University, a Jesuit Catholic university in United States, proposed in 1996, called "centered pluralism," (CP) - a positional approach that they initiated in the context of increasing religious diversity in their academic community. Defined by Gillis $(2013,1)$ as a posture of remaining in the Catholic tradition (center) while engaging in conversation with religious others (pluralism): while it appears to privilege the confessional tradition, it does not in anyway ignore, neglect, or attack people of other faiths but instead recognizes them in the spirit of mutual respect and dialogue. This is after all the true meaning of what it means to be a Catholic (universal) university, one of the main attributes of which is a dialogical approach, according to John Paul II in Ex Corde Ecclesiae.

Besides cultural dialogue, a Catholic University, in accordance with its specific ends, and keeping in mind the various religious-cultural contexts, following the directives promulgated by competent ecclesiastical authority, can offer a contribution to ecumenical dialogue. It does so to further the search for unity among all Christians. In inter-religious dialogue it will assist in discerning the spiritual values that are present in the different religions. (1990, para. 47)

As a framework for teachers, CP complements the SCL paradigm. CP's positional posture provides Catholic teachers a clearer sense of direction on how to allow space for their students to construct their own learning while remaining faithful to the core of Catholic faith. After all, "dialogue" is a central attribute of Catholicism in the modern world which extends even into academic space (Vatican II, 1965, para. 28). As SCL promotes an improved learning environment for the learners, CP directs the professors' teaching style and classroom management. The former benefits the learners; the latter guides the teachers.

First and foremost, any attempt to (re)appropriate CP into the Philippine's local situation necessitates exposing the social context of CP's emergence and analyzing those traces and cues embodied in its history and evolution. While Georgetown proposed CP in response to religious diversity (multi-religiosity) within academic space, the underlying concepts of CP have long been accepted as America's sociopolitical strategy for addressing multiculturalism - respecting (cultural) diversity while placing everyone under one "unifying core culture" (principle) (Moore, 2003, 147). The ideological character of CP as seen in its sociopolitical context is crucial and unmasking it can have significant impact on the project of (re)appropriation.

This paper is concerned with both learners and teachers. Learners, particularly the non-Catholics, who, because of their (non)religious status, are disadvantaged from the outset; they are required to take up Catholic theology/catechesis 
along with their Catholic classmates who have received Catholic education since grade school and/or have been familiar with Catholic practices and traditions as they grew up. As for the teachers, this paper addresses the pedagogical confusion that besets them when they are obligated to empower students as co-creators of knowledge and learning and to be mindful of the duty and prescription of the institutional leadership to promote Catholic heritage through sound and faithful Catholic theology/catechesis.

\section{2 | THE CENTERED PLURALISM OF GEORGETOWN UNIVERSITY}

It is crucial to understand how CP differs in nuance between the Georgetown version and the American nation-state variant. In response to cultural diversity largely created by waves of migration in its long history as a nation-state, CP has been America's ideological framework for respecting ethnic minorities while unifying them under one cultural core (Moore, 2003, 147) of the so-called American ethos of democracy, rights, liberty, opportunity, and equality. There is deliberate political impetus to anchor all ethnic communities, despite respecting their uniqueness, into one American culture.

America's ethnoracial diversity extends to America's educational space and many studies have been devoted to promoting multicultural approaches to education predicated on the basic principle of equity or fairness (Banks, 2008; Labaree, 1997; Levinson, 2010). The objective is to remove any barrier that advantages a dominant cultural group at the expense of other students from cultural minorities. The term of reference is culture and inequity occurs when a certain policy, situation, or practice contributes to inequality in academic performance. For example, refugee students may struggle in school due to lack of familiarity with customs and nuances of the host nation, placing them in a disadvantaged position.

As a country with long and rich history of immigration, American Catholic education embraced a fortress ideology back then to protect its increasing Catholic population, mostly migrants, from the ingrained Protestant American public education system (Cattaro \& Cooper, 2007, 71; O'Keefe, 2000). In the interest of protecting the Catholic youth from Protestant religion, the Church established parish-based schools across many areas in the country (Cattaro \& Cooper, 2007, 70). But this project of protectionism did not last long. Later generation Catholics "became quite 'Americanized' as aspects of the Old World devotional culture and theology were gradually left behind and shades of a new, more individualistic, and democratic Catholicism appeared" (Cattaro \& Cooper, 2007, 71). Based on this development as well as the demand from Vatican II to be more inclusive, dialogical, and ecumenical, protectionism has since been replaced with educational reforms in the Catholic educational system that value diversity, "transforming themselves [Catholic schools] from institutions that convert, assimilate, and protect to institutions of pluralistic complexity" (Cattaro \& Cooper, 2007, 71).

In Georgetown's case, the educational inequity it addresses, insofar as CP is concerned, is the disadvantaged position of non-Catholic students in its academic community. Founded in 1789 during the period of Protestant hegemony and a society with strong anti-Catholic sentiment, Bishop John Carroll, its founder, wanted Georgetown to be open to all students regardless of religious affiliations. In the first ten years of its existence, nearly one-fifth of its students were Protestants while the rest were Catholics. In recent years, about fifty percent of student population are non-Catholics, religiously affiliated to diverse religious traditions (Protestantism, Islam, Judaism, Hinduism, Buddhism, Latter-Day Saints) including students not affiliated with any religious tradition (Gillis, 2013, 1). In 1996, after a series of monthly consultations and conversations involving the faculty and administration, Georgetown embraced a posture that would define its institutional approach to increasing religious diversity within its campus. Striking a balance between the particularity of its religious identity, heritage, and mission as well as its desire to remain relevant and responsive to ever-growing diversity of its academic community, Georgetown embraced CP where Catholicism anchors or centers its identity but its religious identity as reflected in its students and faculty is pluralistic. This underscores to non-Catholics who attend or work at Georgetown that they have a place in the conversation while the core identity of the institution, appropriately, resides in Catholicism (Gillis, 2013, 6). 
The sociopolitical variant of CP is differently nuanced than that of Georgetown. The American nation-state understanding of CP appears inclusive and prescriptive in the context of cultural pluralism. It respects diversity while at the same time prescribing that everyone embrace a core cultural identity. On the other hand, Georgetown CP primarily operates within the context of religious pluralism; it respects the rights and privileges accorded to those whose religious affiliations and beliefs are different from the religious identity of the institution while avoiding any agendum of placing the non-Catholics under one unifying core religious orientation. Although the core identity is pronouncedly Catholic, there is no obligation for religious others to embrace the institutional core identity of the university.

Georgetown's embrace of CP is not without any criticism. In a report by The Cardinal Newman Society (2013) entitled, "Catholic Identity Concerns at Georgetown University," Georgetown's promotion of "centered pluralism" and its glorification of "diversity" on the campus are noted as jeopardizing its Catholic identity. "Georgetown University seems to have decided that serving students of multiple faith means compromising its commitment to the one Catholic Faith" $(2013,12)$. But what the Society fails to remember is that ever since its beginning, Georgetown has thrived within a situation of religious diversity and was founded with openness to other religious perspectives and identities. In essence, Georgetown is an institution predicated on the context of diversity and any accusation of its perceived neglect of Catholic identity has not fully understood the societal context of its birth and evolution.

For Georgetown, appreciation of diversity is an institutional core value. It believes that by appreciating campus diversity, it mirrors the kind of (religiously-)diverse world that awaits the students once they graduate. It prepares its students for the challenges of the real world by replicating on campus the tensions experienced by people in a pluralistic society. While remaining centered in Catholicism, it respects the plurality of religions present on the campus. Still there will always be groups whose deeply conservative Catholic religiosity would rather opt to be shielded from anything non-Catholic and would form an enclave among peers, or perhaps some of the religious Others will remain suspicious of the welcoming embrace of the Catholics and retreat back to their own space of seclusion. But is that not how the world is? The public space is replete with tension, isolation, seclusion, and parallel communities despite the ideals of dialogue, mutual respect, and integrated communities. In academic space, the ideal is not always easy to achieve but committing to its pursuit is always part of Georgetown's foundational mission as both Catholic and Jesuit.

Inside the classroom setting, CP allows Catholic theology to assume a more dialogical and relational posture with other religious faiths and philosophical perspectives. It is neither a position where Catholic theology is presented in isolation with other religious and theological frames nor a surrender of its theological truths to accommodate other beliefs. Centered pluralism is construed as a critical challenge or an antithesis to a theological pedagogy that presents Catholic truths in contrast with other religions or that overcasts the religious others' beliefs with overwhelming Catholic apology and counter-narratives. For Gillis (2013, 2-3), historical formation of Catholic theology rested on its desire to be distinct from other existing beliefs of that time and it was a successful endeavor; Catholicism achieved independence and unique identity. But today's situation demands that Catholic theology is taught and learned in relation to other religious truths and cosmologies. It may not be enough to simply allow a space for these religious others to articulate their faith and practice it. It may be worthwhile too to challenge them to seek the value of their own religious truths in relation to Catholic faith and vice versa through constructive engagement in an environment of dialogue, conversation, and mutual enrichment. It is within this specific ideal of interfaith encounter that both Catholics and non-Catholics learn from each other by listening from both the words expressed by religious others and the thoughts that are products of self-introspection and critical evaluation of one's own religious perceptions.

\section{3 | THE STATE OF CATHOLIC EDUCATION IN THE PHILIPPINES}

The Philippines is predominantly a Catholic nation with $81 \%$ of its population identified with Roman Catholicism. Filipinos' sociocultural normative and lifeworld is deeply imbued with Catholic cosmologies and expressions. Birth until death and significant life moments in between are associated with important Catholic rites and rituals, particularly sacraments. 
Filipinos are religiously devoted but are generally uninformed of the contents of faith. "Sacramentalized but not yet evangelized" (Catholic Bishops Conference of the Philippines [CBCP], 1997, para. 1590), Filipinos' fiducial aspect is centered more on external expressions like veneration of images, processions, and fiestas. Catholic schools, colleges, and universities are expected to play a huge role in filling this dearth of theological orthodoxy among Filipino Catholics. In fact, in the 2012 celebration of the 400 years of Catholic education in the Philippines, the CBCP issued a pastoral letter to Catholic educational institutions highlighting their obligation towards evangelizing the faithful especially the young (Palma, 2012). Across the country and in every town and city, private schools have mostly been owned, supervised, and run by Catholic religious congregations and parishes. Even when some private schools are exclusively owned by lay people, they mostly incorporate Catholic education in their curriculum, particularly in their values education. Similarly, a majority of public/government schools allow parish-based catechists to visit classrooms for basic catechesis of students. Because of this, CBCP proudly exclaims that Catholic education has "laid the foundations of education in the country" (Palma, 2012).

Alongside or despite a confessional theology/catechesis, Catholic academia has generally been favored by most Filipinos given its educational quality. In recent years, Catholic schools in general have outperformed state-run public schools. In the 2016 QS University Rankings for Asia, seven of the eight Philippine universities that qualified rankings are Catholic universities. This academic reputation enjoyed by many Catholic academic institutions has attracted even the non-Catholic Filipinos, despite the institutional academic policy of compulsory Catholic-based theology/catechesis subjects for all students regardless of religious affiliations, as prerequisite to completion of any college degree.

Not only are theology/catechesis classes being populated by non-Catholic Filipinos, there is an increasing number of foreign students who bring along their own (non-)religious identities. Together, both non-Catholic Filipinos and foreigners make up the non-Catholic students in a Catholic-based theology classroom.

With student mobility becoming a global phenomenon and further reinforced by universities' goal to internationalize, academic spaces have seen a significant influx of foreign students. Tayag notes that many of these inbound foreign students are attracted by the country's "use of English as medium of instruction, diverse academic programmes, low cost of living, affordable school tuition fees, and peoples' hospitality" (2013, 63). Classrooms have not only become diverse and plural in terms of culture, ethnicity, and religious affiliations, their demographic makeup has also offered a strong impetus to improving pedagogy in ways that provides greater learning opportunity for all students coming from different contexts and situations.

\section{I RETHINKING PEDAGOGY: A STUDENT-CENTERED THEOLOGY}

Shifting from a teacher-centered approach, current trends in educational research have emphasized the position of learners as central to an effective pedagogy. Referred to by different names, student-centered pedagogy is a fundamental framework that "place[s] the student (learner) in the center of learning process" (Collins \& O'Brien, 2003, 338-339). Described by Barr and Tagg as a shift from "instruction paradigm" to "learning paradigm" (1995, 15), its obvious focus is the "learning" dimension and/or the learners' situation. Students are no longer mere recipients of knowledge but "are treated as co-creators in the learning process, as individuals with ideas and issues that deserve attention and consideration" (McCombs \& Whistler, 1997, 11). Froyd and Simpson (2008, para. 8) narrate how students have reported improved learning when faculty members adopt $\mathrm{SCL}$ in their pedagogy.

Attempts to rethink pedagogies that would cater more to student learning than to teaching dynamics before $\mathrm{SCL}$ have historically occurred earlier than one might expect and surprisingly occurred within the field of theology/catechesis. This is where earlier articulations of a student-centered pedagogy was initially envisioned. In the aftermath of Vatican II, a 1968 article from The Heights, the student newspaper of Boston College, narrated the vision of American Catholic academia adopting a "student-centered" theology that could "meet the student where he is; discussing and working through his experience" (Golenski, 1968, 3). It was an initiative reacting against 
a theology curriculum that adopted a seminary-inspired approach of "corpus doctrinae," that merely presented students with "given truths." In one of its workshops, the participants (led by Rev. Locigno of Manhattan College) agreed upon a "pastoral" orientation in teaching theology, defined as an "abiding attitude and desire to do whatever we can to help our students grow in their humanity and in their freedom - in short - to improve as human beings" (Golenski, $1968,3)$. A different approach was proposed to replace the pre-Vatican II theological pedagogy that was doctrinecentered and catered to nurture the soul of a human person referred to in Platonic sense as an "embodied spirit." With a number of new developments after Vatican II, particularly the return to the historical Jesus as scholarship in the 60s and 70s; the global introduction of liberation theology as a theological framework; and the rise of critical pedagogy as an aftermath of Freire's 1968 book, The Pedagogy of the Oppressed among others, teaching theology/catechesis started to adopt student-centered approaches. Social scientific frames like history, cultural studies, anthropology, and so forth begin being utilized to analyze situations and phenomena for theological reflections and interpretations. Lived experiences are acknowledged as possible sources of theologization in an attempt to empower learners and theology is always born and situated in context.

\section{5 | THE FILIPINO CONCEPTION OF SELF/OTHERS: FRAMING THE "OTHERS" AS KAPWA}

It is crucial in any attempt to (re)appropriate CP into a local situation to uncover any ideological nuances that are tied up with the concepts of the "self" and "others," in the contexts of both its origin (West/America) and destination (Philippines). Much has been said about how the Western conception of self and others is different from how non-Western cosmology understands them. Spiro (1993, 115-116) analyzed a significant sample of anthropologists and social psychologists (Dumont, 1985; Kirkpatrick \& White, 1985; Marsella, 1985; Sampson, 1988; Shweder \& Bourne, 1984) and found that there is indeed a bipolar type of self differentiated between the Western and nonWestern cosmologies. In general, there seems to be agreement that the West understands self to be characterized by personal individuation and autonomy whereas the non-Western understandings of self are characterized by interdependence, dependence, and fluid boundaries. The non-Western concept of other is less discriminating than the West's and is enveloped within the understanding of self as part of a collective whole. For Asians, to treat self in isolation from the group is completely unthinkable (De Guia, 2005, 8; Gnanapragasam \& Fiorenza, 2008, 38-39). With more emphasis on the self's group identification, an Asian understanding is generally believed to be more open and less-resistant to the presence of the other. Spiro $(1993,117)$, however, finds this bipolar understanding of self viewed through the Western and non-Western binary problematic, peculiar, overly generalizing, and non-representational of the actual population. He contends that the differences in understanding of self/others should not be viewed only through the Western and non-Western binary as it is too broad; such differences appear across all societies/cultures. A Filipino understanding of self/other is different, at least to some degree, from the Japanese or Indian conception of self/other. Henceforth, it is very important that any reappropriation of a foreign entity into local context be done with great care to understanding local conditions, cultural nuances, and context.

Filipino (indigenous) psychology understands self with strong relationality with the "other" in an inclusive way. The other is treated as a kapwa, a shared self. Kapwa is a Tagalog term widely used when addressing another with the intention of establishing a connection. By default, the dispositional intention of kapwa is to connect, relate, and share. The very essence of self is tied up with others inasmuch as the existence of kapwa is dependent upon the self's relationality with the other/s. In kapwa cosmology, the self ceases to be when not shared with others and vice versa. It reflects a perspective that links (includes) people rather than separates (excludes) them from each other. Kapwa looks beyond outer trappings for what people have in common: not whether someone is rich or poor, not whether somebody is young or old, man, woman, or child, but rather for the fundamental characteristics in people, that is, as human beings. According to this type of thinking, people always remain just people (tao lang) despite titles, prestigious positions, or wealth (De Guia, 2005, 8). What this means is that Filipinos' kapwa mentality highlights 
commonality rather than diversions and differences and may minimize alienating situations experienced by foreigners and guests. Reyes emphasizes a more communal nuance of kapwa by defining it as "together with the person... where the starting point [of kapwa] is 'together'" $(2015,156)$. This is an important element when considering the presence of religious others in theology classrooms as Filipinos may have in them an inherent psychocultural normative to treat others more genuinely.

Moreover, Enriquez adds that this recognition of self as a shared identity with others starts with oneself and not from others.

A person starts having kapwa not so much because of a recognition of status given to him by others but more because of his awareness of shared identity. The ako (ego) and the iba-sa-akin (others) are one and the same in kapwa psychology: Hindi ako iba sa aking kapwa (I am no different from others). Once ako starts thinking of himself as separate from kapwa, the Filipino "self" gets to be individuated in the Western sense and, in effect denies the status of kapwa to the other. By the same token, the status of kapwa is also denied to the self. $(1978,106)$

In kapwa framework, the starting point is one's commitment to relate with others, even though genuine interconnectedness does not happen in an instant. Meeting and encountering the other involves stages of interactions where Filipinos' treatment of the other can be categorized from mere civility to authentic oneness. Santiago and Enriquez (1976) divide these levels and modes of social interaction into two categories: the Ibang Tao (outsider) and the Hindi Ibang Tao (one of us). When the other is regarded as Ibang Tao, any interaction can range from pakikitungo (civility), to pakikisalamuha (act of mixing), to pakikilahok (act of joining), to pakikibagay (conformity), and to pakikisama (being united with the group). When regarded as Hindi Ibang Tao, the level of interaction is more genuine, from papakikipagpalagayang-loob (act of mutual trust), to pakikisangkot (act of joining others), and to the highest level of pakikiisa (being one with others). For Enriquez, while all these variations in interactions are the result of the kind of relationships one has with others, all of these can be subsumed under an umbrella term: pakikipagkapwa (1992, 52). It is the ultimate Filipino interpersonal behavior and means accepting and dealing with the other person as equal, as human, as a shared self.

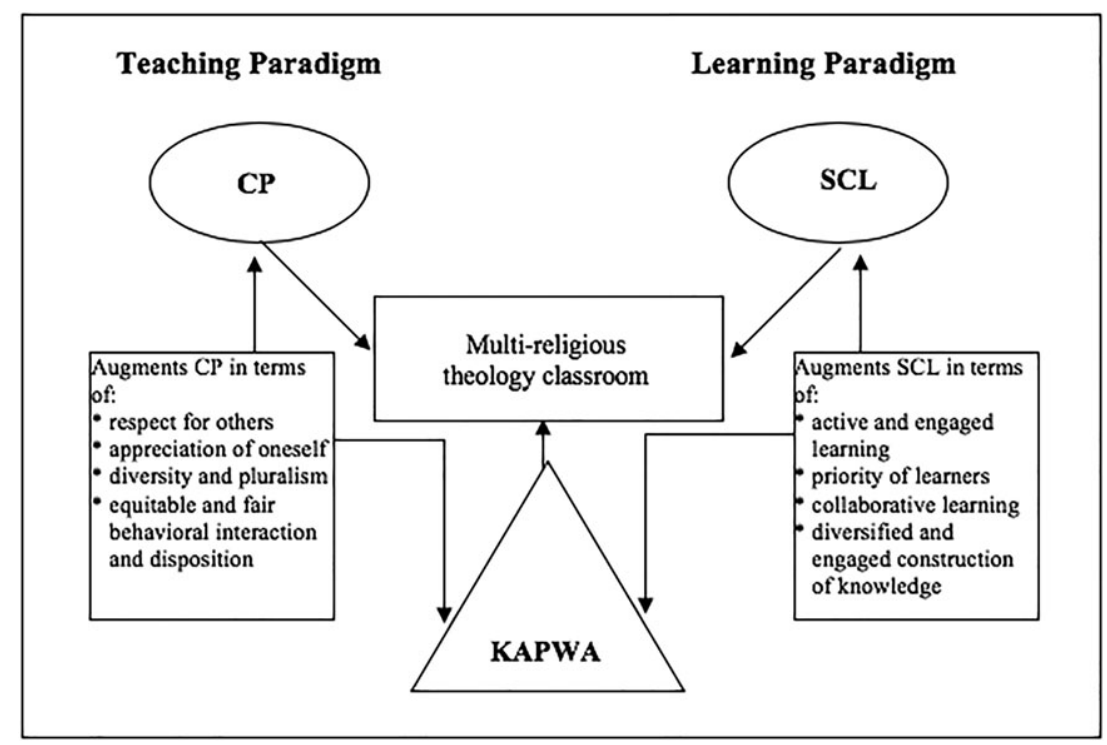

FIGURE 1 The augmenting impact of kapwa on both SCL and CP paradigms as applied in a multireligious theology/ catechesis classroom 


\section{I ASSESSING THE IMPACT OF KAPWA FRAMEWORK TO A MULTIRELIGIOUS THEOLOGY/CATECHESIS CLASSROOM}

What a kapwa framework could mean for a multireligious theology classroom is a (pre)disposition towards an environment of learning and intersubjectivity that is marked by collaboration, dialogue, and communion. Circumscribing the SCL paradigm within a kapwa mentality, each and every participant inside the classroom is treated with dignity and is affirmed as a significant contributor to the articulation of faith and religious reflections. It does not merely allow space for constructing learning, kapwa ensures that such space is nurtured by values of affirmation, acceptance, and respect regardless of cultural or religious differences. It also supports collaborative learning and expects a diversified and engaged construction of knowledge. Adding kapwa to CP enriches respect for others and appreciation of oneself and affirms diversity grounded on an equitable and fair behavioral disposition even to non-Catholics and religious others.

Figure 1 below shows the impact of kapwa in a theology/catechesis classroom that is marked by multireligiosity and follows both $\mathrm{SCL}$ as a learning paradigm (for learners) and $\mathrm{CP}$ as a teaching paradigm (for teachers). It shows that when CP is (re)appropriated in theology/catechesis classrooms in the Philippines, the very conception of self/others within the cultural nuance of kapwa brings forth an enriched understanding of how theology/catechesis teachers must position themselves with respect to the presence of religious others - with higher degree of respect, acceptance, and collaboration. While the central axis is still anchored on Catholic identity and heritage, the behavioral value of kapwa necessitates that the teacher be open for interaction and sharing. The success of a kapwa-inspired theological/catechetical pedagogy starts with the teacher. Such relationality may not be as obviously emphasized within the concept of CP but within the kapwa frame, the teacher cannot help but relate and engage. Similarly, $\mathrm{SCL}$ as a learning paradigm when integrated with kapwa pushes learners not merely to construct learning by themselves, in isolation from others. On the contrary, kapwa legitimates an important core of active learning that is sometimes ignored - the practice of collaborative learning where knowledge is created not only by oneself but with colearners.

Interestingly, kapwa complements both the learning paradigm of SCL and the teaching paradigm of $\mathrm{CP}$ while enriching both the learners' active learning and the teachers' positional posture and direction in teaching theology/catechesis in a multi-religious classroom in the Philippines.

\section{7 | CONCLUSION}

Diversity is the norm in today's educational spaces brought about by recent phenomena of global migration, international student mobility, and internationalization of universities, among other reasons. And this trend will continue. Catholic universities, at least in the Philippines, have witnessed this emerging reality and with it a growing commitment to stay relevant and be responsive to shifting campus demographics. Structural and policy reforms have been initiated by institutions - from creation of offices to help meet international students' needs and concerns, organization of intercultural fairs and festivals for cultural awareness, cross-cultural exchanges and interactions through workshops and seminars, and culturally-inclusive curricular designs - but there is still a shade of ambiguity in the specific space of theology/catechesis inasmuch as it is a required/mandated curricular subject for degree completion.

Despite this normative character of (religious) diversity within theology/catechesis classrooms, the dilemma is, how can theology/catechesis teachers teach the subject within a student-centered framework of active and engaged learning without sacrificing their obligation to teach the content of faith from a Catholic tradition? This paper posits its exposition and analysis from within this cloud of confusion. By attempting to (re)appropriate CP, a Western construct, into the Philippine multireligious classroom, this paper proposes that utilizing the local concept of self/others circumscribed within the Filipino indigenous concept of kapwa is a good solution. Incorporating kapwa augments the 
basic foundational thesis of $\mathrm{CP}$ in respecting others. In kapwa mentality, there is a conscious shift away from merely considering the other as different from self because the other is actually a shared self. The self's ontological existence is to relate with the other. Moreover, kapwa also augments a particular tenet of SCL which posits that learning is not only personal or self-initiated but is also collaborative and group-oriented.

Admittedly, the extent to which this paper attempts to (re)appropriate CP in local context is limited to how CP's positional posture/philosophical orientation in dealing with others in relation to self is enriched, augmented, and reinforced by the kapwa paradigm. While this paper does not posit any specific practice or pedagogical methodology that reflects a (re)appropriated CP in a Philippine situation (which may be a topic for future research project), the paper contributes to strengthening the applicability of $\mathrm{CP}$ as a teaching paradigm for teachers in a multireligious classroom, particularly in the Philippine situation. With kapwa-infused CP, teachers may achieve not just clarity in pedagogical objective/direction but also dispositional posture/orientation towards interdependent and inclusive theological/ catechetical education. Also, in a kapwa-infused SCL, collaborative learning reinforces the knowledge construction and meaning-making of students who look upon themselves as a community of learners.

In the end, what this paper encourages is a critical articulation of the increasing religious diversity in academic spaces particularly within a theology/catechesis classroom that is institutionally mandated to remain faithful to Catholic tradition. Integrating kapwa has shown that any (re)appropriation of the basic tenet of CP into the local context is not only feasible, but that CP, practiced in the Philippines would assume a different form, one that is more otheroriented and less alienating precisely because of the intersubjective character of kapwa in reference to self/others vis-a-vis the Western duality of self versus others. Proposed as a pedagogical strategy, hopefully future articulations of this topic will include assessments, evaluation, and even suggestions to improve the project of religious inclusivity in Catholic universities in the light of kapwa paradigm. This is a continuing project, especially with the growing trend of student mobility. The project is not to take down any Catholic ideal but just to make this ideal relevant, tangible, and conversant to learners' situation, lifeworld, and cosmology.

\section{BIBLIOGRAPHY}

Aleshire, D. (2008). Earthen vessels: Hopeful reflection on the work and future of theological schools. Grand Rapids, MI: Eerdman. Banks, J. (2008). An introduction to multicultural education (4th ed.). New York, NY: Pearson.

Barr, R. B., \& Tagg, J. (1995). From teaching to learning - A new paradigm for undergraduate education. Change: The Magazine for Higher Learning, 27(6), 12-26. https://doi.org/10.1080/00091383.1995.10544672

Bevans, S. B., \& Schroeder, R. P. (2004). Constants in context: A theology for mission today. Maryknoll, NY: Orbis Books.

Brookfield, S. (1995). Becoming a critically reflective teacher. San Francisco, CA: Jossey-Bass.

Cardinal Newman Society, The. (2013). Catholic identity concerns at Georgetown university. Retrieved from http:// cardinalnewmansociety.org/wp-content/uploads/Dossier-Catholic-IdentityConcerns-at-Georgetown-Updated-Jan2017.pdf

Catholic Bishops Conference of the Philippines. (1997). Catechism for Filipino Catholics. Manila: ECCCE Word and Life Publications.

Cattaro, G. M., \& Cooper, B. S. (2007). Developments in catholic schools in the USA: Politics, policy, and prophesy. In G. R. Grace, \& J. O'Keefe (Eds.), International handbook of Catholic education: Challenges for school systems in the 21st century (pp. 61-83). Netherlands: Springer, Dordrecht.

Collins, J. W., \& O'Brien, N. P. (2003). Greenwood dictionary of education. Westport, CT: Greenwood.

Cooper, J. L., MacGregor, J., Smith, K. A., \& Robinson, P. (2000). Implementing small-group instruction: Insights from successful practitioners. New Directions in Teaching and Learning, 81, 64-76. https://doi.org/10.1002/tl.8105

Cooper, M. M. (1995). Cooperative learning: An approach for large enrollment courses. Journal of Chemical Education, 72 , 162-164. https://doi.org/10.1021/ed072p162

De Guia, K. (2005). Kapwa: The self in the other worldviews and lifestyles of Filipino-culture bearers. Pasig City: Anvil Publishing.

De Guzman, A. (2004). The hermeneutics of learner-centered approaches and initiatives in the Philippine basic education sector. Educational Research for Policy and Practice, 3, 223-241. https://doi.org/10.1007/s10671-005-4311-z

Dumont, L. (1985). A modified view of our origins: The Christian beginnings of modern individualism. In M. Carrithers, S. Collins, \& S. Lukes (Eds.), The category of the person (pp. 93-122). Cambridge: Cambridge University Press. 
Enriquez, V. G. (1978). Kapwa: A core concept in Filipino psychology. Philippine Social Sciences and Humanities Review, 42, 100-108.

Enriquez, V. G. (1992). From colonial to liberation psychology. Quezon City: UP Press.

Felder, R. M., \& Brent, R. (1999). FAQs II: Active learning vs. covering the syllabus and dealing with large classes. Chemical Engineering Education, 33(4), 276-277. Retrieved from http://www4.ncsu.edu/unity/lockers/users/f/felder/public//Columns/FAQs-2.html

Froyd, J., \& Simpson, N. (2008). Student-centered learning addressing faculty questions about student centered learning. Course, Curriculum, Labour, and Improvement Conference, 30(11). Retrieved from http://ccliconference.org/files/2010/ 03/Froyd_Stu-CenteredLearning.pdf

Georgetown University. (2019). Spirit of Georgetown values. Retrieved from https://missionandministry.georgetown.edu/ thespiritofgeorgetown/values

Gillis, C. (2013). Welcoming the religiously other to a Catholic university. Integritas, 1(3), 1-18. https://doi.org/10.6017/ integritas.v1i3p1

Gnanapragasam, P., \& Fiorenza, E. S. (Eds.) (2008). Negotiating borders: Theological explorations in the global era. Delhi: Indian Society for Promoting Christian Knowledge.

Golenski, J. (1968, June 28). A 'student-centered' theology. The Heights. Retrieved from https://newspapers.bc.edu/?a=d\&d= bcheights19680628.2.13

John Paul II. (1990). Ex corde ecclesiae. Retrieved from http://w2.vatican.va/content/john-paul-ii/en/apost_constitutions/ documents/hf_jp-ii_apc_15081990_ex-corde-ecclesiae.html

Kirkpatrick, J., \& White, G. M. (1985). Exploring ethnopsychologies. In G. M. White, \& J. Kirkpatrick (Eds.), Person, self, and experience: Exploring pacific ethnopsychologies (pp. 3-32). Berkeley, CA: University of California Press.

Labaree, D. F. (1997). Public goods, private goods: The American struggle over educational goals. American Educational Research Journal, 34, 39-81. https://doi.org/10.3102/00028312034001039

Levinson, M. (2010). Mapping multicultural education). In H. Siegel (Ed.), The Oxford handbook of philosophy of education (pp. 428-450). New York, NY: Oxford University Press.

Marsella, A. (1985). Culture, self, and mental disorder. In A. Marsella, G. DeVos, \& F. Hsu (Eds.), Culture and self: Asian and American perspectives (pp. 281-308). New York, NY: Tavistock Publications.

McCombs, B. L., \& Whisler, J. S. (1997). The learner-centered classroom and school: Strategies for increasing student motivation and achievement. The Jossey-Bass Education Series. San Francisco, CA: Jossey-Bass Inc.

Moore, J. (2003). A critique: A case for centered pluralism. Curriculum and Teaching Dialogue, 5(2), 147-149.

O'Keefe, J. M. (2000). Leadership in urban Catholic elementary schools: The reality and the challenges. In T. Hunt, T. Oldenski, \& T. Wallace (Eds.), Catholic school leadership: An invitation to lead (pp. 225-243). New York, NY: Falmer Press.

Palma, J. (2012). Pastoral letter on 400 years of Catholic education in the Philippines. CBCP News. Retrieved from http:// www.cbcpnews.com/cbcpnews/?p=324

QS University Rankings: Asia. (2016). Retrieved from https://www.topuniversities.com/university-rankings/asianuniversityrankings/2016

Reyes, J. (2015). Loob and kapwa: An introduction to a Filipino virtue ethics. Asian Philosophy, 25(2), 148-171. https://doi. org/10.1080/09552367.2015.1043173

Sampson, E. E. (1988). The debate on individualism: Indigenous psychologies of the self and their role in personal and societal functioning. American Psychologist, 43, 15-22. https://doi.org/10.1037/0003-066X.43.1.15

Santiago, C. E., \& Enriquez, V. G. (1976). Tungo sa maka-Pilipinong pananaliksik [Towards a Filipino-based research]. Sikolohiyang Pilipino: Mga Ulat at Balita, 1(4), 3-10.

Shweder, R. A., \& Bourne, E. J. (1984). Does the concept of the person vary culturally? In R. A. Shweder, \& R. A. Levine (Eds.), Culture theory (pp. 158-199). Cambridge: Cambridge University Press.

Spiro, M. E. (1993). Is the Western conception of the self 'peculiar' within the context of the world cultures? Ethos, 21(2), 107-153. https://doi.org/10.1525/eth.1993.21.2.02a00010

Tayag, J. C. (2013). International student mobility: Philippines. The International Mobility of Students in Asia and the Pacific [Electronic version]. Retrieved from http://unesdoc.unesco.org/images/0022/002262/226219E.pdf

Tien, L. T., Roth, V., \& Kampmeier, J. A. (2002). Implementation of a peer-led team learning instructional approach in an undergraduate organic chemistry course. Journal of Research in Science Teaching, 39(7), 606-632. https://doi.org/ 10.1187/cbe.13-08-0168

Vatican II. (1965). Gaudium et spes. Retrieved from http://www.vatican.va/archive/hist_councils/ii_vatican_council/documents/vat-ii_const_19651207_gaudium-et-spes_en.html 
Wuerl, D. (2013). Catechesis and theology in the service of the new evangelization. Retrieved from http://www.usccb.org/ about/doctrine/intellectual-tasks/upload/intellectual-tasks-of-the-new-evangelization-2013-cardinal-wuerl-catechesisin-service.pdf

How to cite this article: Macaraan WER. A kapwa-infused paradigm in teaching Catholic theology/catechesis in a multireligious classroom in the Philippines. Teach Theol Relig. 2019;22:102-113. https://doi.org/10.1111/ teth.12477 